\title{
EQUiLIBRIUM
}

Quarterly Journal of Economics and Economic Policy

2015 VOLUME 10 ISSUE 4, December

p-ISSN 1689-765X, e-ISSN 2353-3293

www.economic-policy.pl

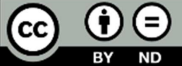

Siddiqui, K. (2015). Political Economy of Japan's Decades Long Economic Stagnation. Equilibrium. Quarterly Journal of Economics and Economic Policy, 10(4), pp. 9-39, DOI: http://dx.doi.org/10.12775/ EQUIL.2015.033

Kalim Siddiqui*

University of Huddersfield, United Kingdom

\section{Political Economy of Japan's Decades Long Economic Stagnation}

JEL Classification: $F 00 ; F 5 ; F 6$

Keywords: Japan; Political Economy; Stagnation; Mounting Debts and growth rates

\begin{abstract}
It is hard to imagine that after Japan's miracle post-war growth it would go on to suffer more than two decades of stagnation. Although there have been some short-lived periods of recovery, such as in 1995-96, the average growth rate over the period of 1991-2014 was a mere 1\%. Despite historically low interest rates and a series of fiscal stimuli, the growth has not revived. Despite the long economic stagnation, Japan still retains its strength in many areas. Its human and physical capital formations are among the highest in the world. The volume it spends on research and development is equally impressive. It still has worldleading firms and modern technologies.

The methodology to be followed here is derived from the aims of the study and comparisons of international statistics provide the main means of addressing the research questions and the objectives of this paper. The study concludes that the neoliberal 'market-centred' policies have brought inequality, stagnation, and fiscal crisis to the state. Therefore, a radical critical political economy is required to analyse the situation more objectively, one which would mean increased levels of welfare and people-led measures.
\end{abstract}

(C) Copyright Institute of Economic Research \& Polish Economic Society Branch in Toruń Date of submission: April 16, 2015; date of acceptance: September 15, 2015

* Contact: k.u.siddiqui@hud.ac.uk, University of Huddersfield, Queensgate HD1 3DG, UK. 


\section{Introduction}

At present, Japan is the third largest economy in terms of GDP. It is also the largest exporter and the third largest importer of raw materials in the world. Japan's mega-corporations with their capital investment in East Asian countries have been effective in inducing their economies and exports in the past. This study is important because the performance of Japan's economy would not only have an impact on its own population, but also on the rest of the global economy. The question arises: Why, after being a star performer in the OECD from 1950 to 1990, has Japan now witnessed economic stagnation for over two decades?

Japan was officially occupied from 1945 to 1952, but the US has maintained a military presence there ever since. Immediately after the Second World War, Japan's economy experienced severe problems, but with the outbreak of the Korean War, its GDP growth increased rapidly.

Between 1950 and 1972, Japan's economy experienced high growth rates of more than 9\% per annum on average (Siddiqui, 2009a), compared to just $3.6 \%$ for the US and $4.7 \%$ for Western Europe during the same period. The oil crisis in 1973, followed by the global economic crisis, slowed down its growth rates. In the case of Japan, lower growth rates returned in 1990-2001 (1.3\%), while in the US this increased to 3.4\% for the same period. However, if average annual growth rates for the period between 1950 and 2000 are examined, we find that Japan performed better (5.7\%) than the US (3.2\%) (Maddison, 1995; OECD, 2013).

For the last two decades, however, Japan's economic performance can best be described as dismal. In the 1980s, it was widely seen as a success story and in the early 1980s, when the US economy was experiencing a severe crisis, Japan was said to be the model to emulate. However, such a statement would be very unrealistic now (Siddiqui, 2009a).

In May 1989, the Bank of Japan began to raise interest rates to dampen speculation. Soon after the bubble burst in 1992, the Nikkei Index fell from 38,915 in December 1989 to 14,309 in August 1992; by 2003 it had declined by a further $50 \%$ i.e. to 7,000. This created a massive asset deflation, which in turn led to a banking crisis in Japan. During the period 19921995 , the yen appreciated by nearly $50 \%$, meaning a huge loss of competitiveness in the export sector for a country like Japan, where until recently exports had contributed hugely towards higher growth rates. With the East Asian crisis in 1997, Japan's export markets dropped further, as East Asian countries buy one-third of Japan's exports. As a result, its exports to East Asia fell by 25\% within the space of one year i.e. 1998 (Siddiqui, 2009a). 
The economic growth collapsed and the macroeconomic troubles seems to have triggered the crisis in the financial sector. Each time the recovery of the Japanese economy looks like it is picking up, it soon after falls back. Japan's economy has virtually stagnated. Some economists blame this on unfavourable shocks that began with bursting of the 'bubble economy', and suggest that the supply side has not changed much during the earlier period of high growth. The solutions lie in the adoption of more suitable macroeconomic policies such as targeting exchange rates, inflation, fiscal spending. While others argue that the problems are far deeper and would require structural reforms (Berry, 2012; Boltho \& Corbett, 2000).

In 1994, Japan's share of global GDP was $17.9 \%$, but by 2011, this had declined to half of this i.e. $8.8 \%$. Japan's share of global trade declined even more sharply to $4 \%$ and the stock market continues to remain at onequarter of its 1990 level. For the past 10 years, its economy has grown at an annual rate of just $0.4 \%$. Unemployment is high by Japanese standards but at below 5\%, it is half the level of many developed countries.

In the late 1990s, the government started to provide subsidies which not only have kept several loss-making "zombie" companies in business, but have also succeeded in discouraging the creation of new businesses in those sectors where the subsidized companies are most prevalent, such as the construction industry. Employment creation and productivity growth also slowed down in "zombie"-dominated sectors (Caballero et al., 2003).

So, what went wrong with the Japanese economy? It is hard to imagine that Japan's miracle post-war growth has now suffered over two decades of stagnation. Although it enjoyed a few short-lived periods of recovery such as in 1995-96, the average growth rate over the period 1991-2014 was a mere $1 \%$. Despite historically low interest rates and a series of fiscal stimuli, growth has not revived. So, what has caused this long stagnation? Whilst it is true that in the 1990s Japan witnessed a number of disasters such as the East Asian crisis (Siddiqui, 2009b) and the Kobe earthquake, such events can hardly explain a two-decade long stagnation.

This study will examine these developments and changes in the Japanese economy, drawing on existing academic literature, and on the basis of a critical review it will try to identify the key reasons which lie behind this decades-long economic crisis.

The article is structured as follows: it begins by providing an overview of the Japanese economic crisis, contrasting this with the post-war economic boom which it experienced. The causes of the slowdown in the Japanese growth rates are then discussed. After examining the country's deepening economic crisis, the ongoing debate about the root causes of the economic 
stagnation and crisis is explored, before closing it with some concluding insights.

The methodology of this paper is based on secondary data. Analysing pre-existing secondary data is the only possible way to obtain macroeconomic data. These include data from official sources and from international institutions, such as the World Bank and UNCTAD.

This study will briefly examine a number of factors which have played an important role in the post-war economic boom in Japan. However, the analysis of neo-classical economists is very narrowly focused, tending to ignore wider social and political aspects which may have impacted on economic performance. They are unable to explain Japan's growth, because the factors that contributed towards it are incompatible with neo-classical economic theory (World Bank, 1993; Krugman, 1994; Little, 1982). Their flawed model also means that they are unable to explain the on-going stagnation in Japan's economy. This being the case, a less orthodox approach may offer a more comprehensive explanation of Japan's political economy including its current decades long economic stagnation.

\section{The High Growth Era - 1950-1972}

Following Japan's defeat in the Second World War, its economy experienced a number of problems, not least of which was what to do with its vast army of 7.5 million troops and the dismantling of its military and armament production (Tsuru, 1993). A number of policy measures were taken, which later proved to be crucial in boosting the domestic economy.

Firstly, the early post-war economic reforms introduced by the occupying forces included the dissolution of the zaibatsu, which were conglomerates of big business groups, viewed suspiciously by the US. During the war, they had been closely allied with the military and were seen by the US as having benefited from the war economy. The zaibatsu had been favoured by the Japanese government in the pre-war period through various measures such as offering them subsidised funds, lower taxes and government contracts to supply goods to its armies. These big business groups were also involved in the production of armaments materials during the war (Tsuru, 1993).

Secondly, the land reforms initiated by the US occupying forces not only addressed rural inequalities, but also increased agricultural output. At that time, it was considered that land reforms were necessary to democratise the country since at the end of the Second World War, concentration of land ownership posed a major problem in Japan. Some $50 \%$ of the land was 
owned by absentee landlords, $70 \%$ of the farmers were tenants and $68 \%$ of the total farm output was paid to landlords in rent. After the war, there was an obvious need for radical measures in order to introduce rural equality and raise agricultural incomes and output(Tsuru, 1993).

General MacArthur, who then headed the US forces, strongly supported the government bill on "Rural Land Reforms" in 1946. As Harrison (1983, p. 168) notes:

"The post-war reform sought to eliminate the despised landlords by increasing the number of owner-occupiers [...] transforming tenants into owners."

Almost all land was purchased by the government and then sold to the tenants on easy terms. As a result by 1955 , a total of 1,742,000 hectares of cultivated land had been transferred to 4,478,000 tenants, who became independent farming households. The government also reduced rents (Dore, 1971; Ogura, 1967). In short, the post-war land reform in Japan brought tremendous changes in the structure of land ownership and the rural economy, bringing new vitality to agricultural growth. It aimed to break the land monopoly (i.e. agricultural estates and absentee landholders) in Japan and transfer land into the hands of small farmers and tenants.

In 1950, nearly $48 \%$ of the Japanese labour force was still engaged in the agricultural sector, as against 5\% in the UK. However, the rapid postwar growth continuously drew people in from the rural areas to the urban industrial centres and, at the same time, the number of households increased. These increasing job opportunities and incomes helped create rapid expansion in domestic markets and demands for consumer goods. During the post-war economic boom, rapid technical progress was fuelled by high investment in the manufacturing sector along with rising levels of investment in R\&D. From 1960 to 1973, Japan's investment/GDP ratio was $18.5 \%$, as against $10 \%$ for the US for the same period. Buoyant domestic demand provided further incentives to develop and invest in new technologies and products (Yoshikawa, 2000).

The third important factor which contributed to the post-war economic boom was the start of the Korean War followed shortly after by the Vietnam War. It is now widely acknowledged that the Korean War boosted high growth rates in the post-war period and marked the beginning of the long period of economic miracle in Japan (Tsuru, 1993; Itoh, 2000). With the start of the Korean War in 1950, the Japanese trade rose dramatically, boosting its export sector and its economy in general. With increased export earnings Japan was able to import at much higher levels, especially 
high technology and raw materials for use in its industries. For instance, the Japanese imports rose from US\$ 1 billion in 1949 to US\$ 2 billion by the following year.

We should not forget that Japan received huge post-war reconstruction grants in addition to US\$2.2 billion in military procurement orders from the US between 1950 and 1953. Such orders accounted for nearly 65\% of Japanese exports over those years, which could be described as military Keynesian. As Tsuru (1993, pp.77-78) argues:

"though paramilitary demand arose on account of the Korean 'Special procurement', it appeared clear enough during the early occupation years that a major reliance had to be placed on export demand if the economy was to continue on the growth path."

In fact, soon after the Second World War, the geopolitics of the region dramatically changed with the start of the Cold War. This, together with the Korean War boom and the Vietnam War, provided good opportunities for Japanese businesses to expand and promote their interests, allowing them to resurface as a regional power. Under full US military protection, Japan was also spared from military spending and could invest all its energy into investment into consumer goods. The US also lifted the barriers to transfer of modern technologies, its strategic objective being "keeping Japan on our side". Domestically, therefore, the US had to convince businesses, especially the textile industry, which feared Japanese competition. It also had to persuade European countries to open their markets to Japanese products, because of the perceived lack of reciprocity from Japan (Forsberg, 2000; Itoh, 2000)

The manufacturing industry has been at the forefront of Japan's postwar miracle. The rapid expansion of manufacturing output initiated the cumulative increases in output and productivity, which in turn helped its businesses to become more competitive in overseas markets and to expand its export share. When barriers were lifted on importing new technology to Japan, it was able to take advantage of dynamic economies of scale and modify imported technology to enhance productivity. It made best use of imported technology, turning it into low-cost mass production systems. Due to the increased availability of raw materials and technologies, Japanese industry was able to double its scale of production and further decrease the overall costs of production. For example, in the 1960s, its steel industry successfully improved the quality of largely imported technology. Similarly, in the automobile industry, imported technology was applied to improve quality, allowing Japan to later emerge to compete successfully in interna- 
tional markets. Between 1950 and 1972, the Japanese economy experienced an average growth rate of $10 \%$ per annum, made possible due to extremely high investment and very rapid technological progress (Forsberg, 2000).

Wage increases lagged behind productivity growth, which made it possible for continuous growth in the share of profits to go into investment. At the same time, public investment went into infrastructure, especially in $\mathrm{R} \& \mathrm{D}$ and transport, designed to meet business challenges rather than into public spending on welfare, recreation and housing. This skewed public investment towards the capital-goods and export sectors at the expense of wage goods has been the hallmark of Japanese post-war economic development.

Japan's post-war boom was led by Prime Minister Yoshida Shigern, whose primary focus was to modernise the economy through heavy industries. The government later advanced plans to increase both public and private investment. This task was given to the Ministry of International Trade and Industry (MITI), which was regarded as the most powerful organisation during the country's rapid industrialisation period. MITI was assigned to target a small number of industrial sectors such as steel, shipbuilding, chemicals, machinery and electronics which were supposed to help fuel the rapid industrialisation and transformation of the economy and achieve higher growth rates. Large amounts of resources were made available to the chosen industries, the aim being to transform them into global successes.

In the 1960s average wages in the industrial sector were lower than in the US and Western Europe and wage growth in Japan also lagged behind productivity growth. Johnson (1998, p. 653) argues that the East Asian model consists of:

"Asian values on subjects such as the nature of government, priority given to the community over the individual, and government guidance of a nonetheless privately owned and managed market economy, with economic growth tied above all to exports. This contrast with the AngloAmerican emphasis on what westerners claim are universal values: individualism and laissez-faire, with economic growth tied above all with domestic demand."

At the same time, inflows and outflows of capital were closely regulated. As a consequence, foreign corporations found it virtually impossible to penetrate the Japanese market. Johnson (1998, p. 655) argues that the Japanese structures include: 
"cartelisation of the keiretsu-chaebol variety, bank-based systems of capital supply, mercantilism and protectionism vs. external economies, and rule by bureaucratic elites."

and they were designed:

"to enrich the nations of East Asia, not to meet consumer demand, global efficiency, individual choice or any of the other motives posited by neoclassical economics."

The manufacturing sector became the engine of growth in post-war Japan's economic development. The expansion of manufacturing output had a wider impact on labour productivity and technology, which in turn created a rising export sector. Most important development from 1950 to 1990 was therefore driven by investment in heavy industries as it exhibited large sunk costs and economies of scale, which acted as effective barriers to entry. As a result, an oligopolistic industrial structure emerged, known as keiretsu, which included companies such as Mitsubishi, Mitsu, Toyota, Smitomo etc. These large businesses operated a highly hierarchical structure through a subcontracting system with small-to-medium sized enterprise (SMEs). Japanese SMEs are still very important, as they provide employment for $80 \%$ of the labour force. As Tsuru 1993, p. 85-86) explains:

"A particular industry succeeds in becoming an export industry through a resort to the dual price system and then in expanding the scale of production to make full use of the economy of scale so that price and quantity changes become negatively correlated [...] the improvement in productivity in domestic production resulting from larger investments in human and physical capital was actually made possible of the successful in export expansion."

In the Japanese model of strategy frameworks, the state plays a more active role which differs in various ways to the dominant Anglo-American neoliberal economic governance strategy (Siddiqui, 1995). This statedirected model of industrial development was seen as being successful in achieving post-war economic success, since its economy outperformed all the other developed economies (Johnson, 1982). To understand Japan's economic strategy, we must take into account the fact that its government has actively followed an interventionist industrial policy and also that Japanese companies have a unique institutional (production) system of big corporations assisted by small firm production network (Aoki, 1990). These 
SMEs supply intermediate goods, in what is called a 'dual structure'. The relationship between big companies and sub-contractors was often described as a close network, built on the basis of mutual trust, and they worked in close proximity with the large companies in what were known as 'company castle towns', for instance Toyota City. The government also undertook initiatives to support industry by making funds available for industrial supplier associations (Cowling \& Tomlinson, 2011; Sako, 1996).

Aoki (1990) analysed Japanese companies, using what he called the Jmodel, and found it differed from Western companies which were based on the hierarchical H-model based on finance and equity arrangements, employer-labour relations, subsidies, structure, etc. It has been suggested that the Japanese state was able to build a consensus among stakeholders to achieve higher economic performance. However, Japan's experience of nearly three decades of economic stagnation and slow growth has led economists to question the so-called unique Japanese model. Since 1991, the poor economic performance has been remarkably similar to that in the Western countries, where economic power is mainly concentrated in the hands of big corporations. Despite the fact that Japanese big corporations work closely with subcontractors, they control them by dictating contract conditions, imposing technologies and ultimately power among them remains asymmetrical. Burkett and Hart-Landsberg (2000, p. 121) have described the Japanese model as an

"exploitative, hierarchical, undemocratic and expansionist form of capitalism".

It now appears that the strategic interests of big corporations were often pursued at the expense of other stakeholders within the Japanese economy and society (Cowling \& Tomlinson, 2011).

The Japanese case also demonstrates that, with a degree of protectionism, industrial strategy and state investment can deliver a dynamic growth for a (significant) period. However, in the longer term, the case of Japan also highlights that when a corporatist policy is pursued and hierarchical governance structures emerge, then long-term development paths are likely to be determined by the few with the public interest being compromised. This is a crucial lesson for the design of future industrial strategy (Cowling and Tomlinson, 2011, p. 843). 


\section{The Post-High Growth Period - 1973-1991}

In 1973-74 oil prices quadrupled and the fact that Japan was the world's largest importer of oil meant it was worst affected by this dramatic price rise. This oil shock provided a strong stimulus to growth in manufacturing, especially in machinery industries, which had experienced rapid rise in productivity and competitiveness in the 1960-1970s. In addition, the depreciation of yen by $10 \%$ against the US dollar helped the machinery sector to gain price competitiveness internationally. Thus, from 1972 to 1976, the wholesale price index of machinery rose by $25 \%$ in Japan as against $40 \%$ in the US. Given the depreciation of the yen over the same period, the price competitiveness of its machinery improved by $25 \%$ in international markets (Itoh, 2000).

Financialisation of the global economy has increased since the 1980s, a period which also witnessed a series of financial crises. Financialisation of the developed economies seems to have compounded the most exploitative elements of capitalism i.e. intensifying inequality and increasing instability. Instability of the market economies has emphasised the increasing danger of internationalisation of financial market liberalisation based on laissez-faire policies leading to increased economic instability. Laissezfaire policies based on government non-intervention and unregulated markets and flexible exchange rates, have increased the incidence of capital flight, speculation, and exchange rate vulnerability, generating low employment and poor growth performance (Clarke, 2010; Argitis \& Pitelis, 2008).

Firstly, Japan's crises are the result of over accumulation, which is largely due to the structural propensity to build productive capacity while experiencing contraction in effective demand. The investment of the oligopolistic keiretsu, which dominate the economy, depends on effective demand, which ultimately determines the degree of production capacity utilization and ultimately levels of profit. The government is trying to raise effective demand by raising public spending. In 1984, when 250 Japanese yen was being traded for 1 US dollar, the success was attributed to its industrial policy, just-in-time delivery, labour policies and cultural characteristics. However, it seems that the overvalued US dollar or undervalued yen and an expansionary monetary policy contributed to the rapid economic growth rates in the early 1980s. Japan did benefit from the undervaluation of yen against the US dollar (See Figure 1). Kaldor (1971) found that even the United Kingdom raised growth rates by stimulating exports through subsidising them or by undervaluing exchange rates in the 1960s. 
Figure 1. Exchange rates of yen vs. US\$

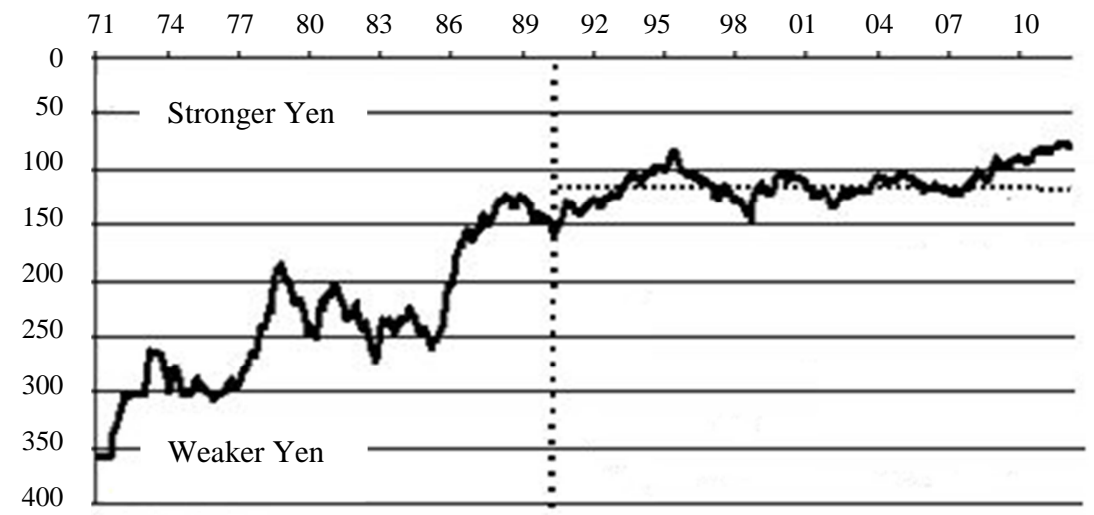

Source: St. Louis Federal Reserve Bank, CFA Institute.

Secondly, the liquidity crisis is associated with the 1985 Plaza Accord, which led to the sharp appreciation of yen against the US dollar. The government attempted to prop up the economy as the appreciation in yen led to a huge build-up of excessive liquidity in the modern period. When the speculative bubble eventually burst in 1991, the economy was caught in a liquidity trap from which it is yet to recover. Soon after the Plaza Accord, Japanese corporations increased their investment overseas, especially in East Asia (Siddiqui, 2012a). Japanese big businesses began to generate internal capital for investment and lowered their excessive reliance on banks. The banks with excessive liquidity turned towards financing reckless speculation in estate, urban property, and stock market. At the same time, the Bank of Japan lowered interest rates and soon after, in 1987, the Ministry of Finance began to pursue an expansionary monetary policy. All these measures led to the build-up of excessive liquidity.

The Plaza Accord appears to have brought major changes. At the beginning of 1985, the exchange rate was 240 Japanese yen for one US dollar. By 1988, yen had appreciated to 125 per US dollar. After the Plaza Accord, exporting capital became more profitable for Japanese corporations, but it did not prove to be a long-term recipe for success. With the overvaluation of yen, Japan's investment was diverted from domestic destinations in favour of overseas low-cost alternatives. Manufacturing investment was diverted from Japan's industrial regions in favour of low-cost overseas destinations. With the overvaluation of the yen and the rising wages in the country, manufacturing investment by Japan's big corporations was diverted from Japan's industrial regions and shifted overseas to alternative low- 
cost destinations. As a result overseas production rose six-fold between 1985 and 2002, which was far higher than any other developed country during this period.

Overseas investment generated income in the form of repatriated profits and dividends and the country joined the ranks of the "rentier" nations. This happened in the second part of the $20^{\text {th }}$ century, when the US maturity was characterized by outflow of capital, which promoted the industrialisation of its rivals, leading to the industrial decline of the US since 1973. However, unlike the US, Japan has been reluctant to transfer strategic technology and knowledge to East Asian countries. Japan's major international competitive advantages are in sophisticated machinery, electronics, computers and robots, and it has focused on technology-based industries which are high value-added and low energy.

Moreover, Japan's persistent trade surpluses have led to the accumulation of huge foreign exchange reserves. Under a flexible exchange rate regime, the accumulation of huge surplus would have led to a spectacular appreciation of exchange rate and ultimately would have eroded export competitiveness. However, Japan countered any possible yen appreciation with export of capital through foreign direct capital investment. The Ministry of Finance was able to limit yen appreciation, either through openmarket operation in close cooperation with the Bank of Japan, or by making an agreement with the US Treasury, as was clearly seen during the Clinton presidency.

\section{The Stagnation Era Since 1992}

Stagnation began in 1991 with the collapse of stock market, land and estate prices. A comparison between 1991 and 2000 shows that during this period the Nikkei share price index fell by $50 \%$, while land prices by $25 \%$ (Mayer, 1999). This massive loss of wealth impacted most severely on business future investments. Whilst company investment had increased by an average of $8.5 \%$ annually in the $1980 \mathrm{~s}$, negative investment was recorded for the period 1990-2014. Consumers, whose disposable incomes witnessed near stagnation, cut back on their spending. The banks, which had extended credit on the appreciating yen, especially after the mid-1980s, found themselves being overtaken by large amounts of non-performing assets, which reduced lending. Failure to tackle these bad loans by the Japanese government added to the crisis (Boltho \& Corbett, 2000). Regarding the mismanagement due at least in part to the favouritism and nepotism rife in the 1980s Johnson notes: "Japan has complacently continued to protect its 
structurally corrupt and sometimes gangster-ridden firms and has made only gestures towards holding anyone responsible. Virtually all its public funds to stimulate the economy have gone into the politically powerful but environmentally disastrous construction industry" (Johnson, 1998, p. 655). Japan's economy stagnated in the early 1990s after the stock market property bubble burst. However, its 2009 economic performance was even more troubling. As The Economist (2009, p. 73) noted at the time:

"Industrial production plunged by $18 \%$ in the year to February, to its lowest level since 1983. Real GDP fell at an annualised rate of $12 \%$ in the fourth quarter of 2009 and may have declined even faster in the first three months of this year [2009]. The OECD forecasts that Japan's GDP will shrink by $6.6 \%$ in 2009 as a whole, wiping out the gains from previous five years of recovery [...] For 16 years the economy has in effect, gone nowhere."

Another symptom of the stagnation is the deteriorating social conditions for working people and also the sharp decline in the average birth rate. Japan's birth rate was above two in 1973, but thereafter fell continuously to 1.29 by 2005 . As a result, Japan's population began to decline and long term predictions have estimated that its population will have halved by the end of the $21^{\text {st }}$ century. This rapid shift to an aged society will bring dramatic change to relatively stable proportions of Japan's post-war economy. Change of this kind will threaten pension plans, medical insurance and education, leading to a budgetary crisis of the state, (Siddiqui, 2014b) and will seriously damage prospects of economic development, including domestic demand and labour supply.

Japan's industrial structure has experienced significant changes since the early 1990s. The most significant developments have occurred since 2005 , when the real effective exchange rate of the yen became more consistent with its long term average. The yen began to appreciate in 1985, peaked in 1995, when its value was $80 \%$ higher than it had been in 1980, and then began to decline until 2007. Yen began this sharp rise relative to the US dollar after Plaza Accord. As a result, the manufacturing sector witnessed contraction. The Japanese government reacted by expanding both fiscal and monetary policies. This coincided with favourable terms-of-trade changes at the time (caused by the decline in oil, gas and primary commodity prices). With the emergence of a bubble economy, the urban and estate property prices rose sharply. To control it, the Japanese government reversed its policies in 1991. The economy entered into long-term stagnation in 1992. For next decade, the annual GDP growth averaged less than $1 \%$, 
causing it to be referred to as "the lost decade". Despite a small rise in growth rates which rose to $2 \%$ in 2003-04, this short-term recovery did not end deflation. During the long period of stagnation, the government eased fiscal and monetary policies in a hope to boost domestic demand and to minimize deflationary pressures. But, thus far, it has failed to produce any viable results (Kawai \& Takagi, 2009).

Tax revenue has declined due to on-going economic stagnation and reduction in corporate taxes. For instance, following neoliberal policies, the corporate tax rate was reduced from $42 \%$ to $30 \%$ and marginal income tax was reduced from $75 \%$ to $37 \%$, accompanied by a reduction in inheritance tax rate, favouring the rich. In contrast with this, a consumption tax of $3 \%$ was introduced in 1989, and subsequently raised to $5 \%$ in 1997 , shifting the fiscal burden on to working people.

From 1992 to 2001, net exports contributed almost nothing to Japan's GDP growth, but then experienced a surge from $11 \%$ to $17 \%$ of the GDP in 2008. As export demand declined sharply, the yen appreciated in 2008, Japan's exports collapsed, total exports falling by nearly half in 2009. Japan's high value products such as electronics and cars were the first commodities that consumers stopped buying during the crisis.

Devaluation of dollar-denominated assets will squeeze profit margins on goods exported to US markets for which there are competitors. The devaluation of the US dollar has stimulated capital exports from Japan into the US, but persistent devaluation does not help the links between Japanese subsidiaries in the US and their home base. Under such circumstances, the higher yen costs of intermediate products and technologies imported from home companies can push up costs. As a result, the Japanese corporations operating in the US are becoming autonomous units i.e. less dependent on imports of products and technologies from the home country, despite the fact that Japanese corporations maintain tight links and control regarding technology transfer (Gilpin, 2000).

Figure 2 indicates that US rates of growth were higher in the 1960s than 1970s and Japan's growth performance was much better than that of the US and Europe between 1960 and 1989. In the decade 1990-2000, Japan's growth rates were lower than those of other developed economies such as the US and the EU. Furthermore, according to the figures between 2000 and 2011, the Japanese economy declined even further, growing at almost half the rate of earlier decades. 
Figure 2. GDP growth rates of the developed economies (Percentage Real GDP Growth)

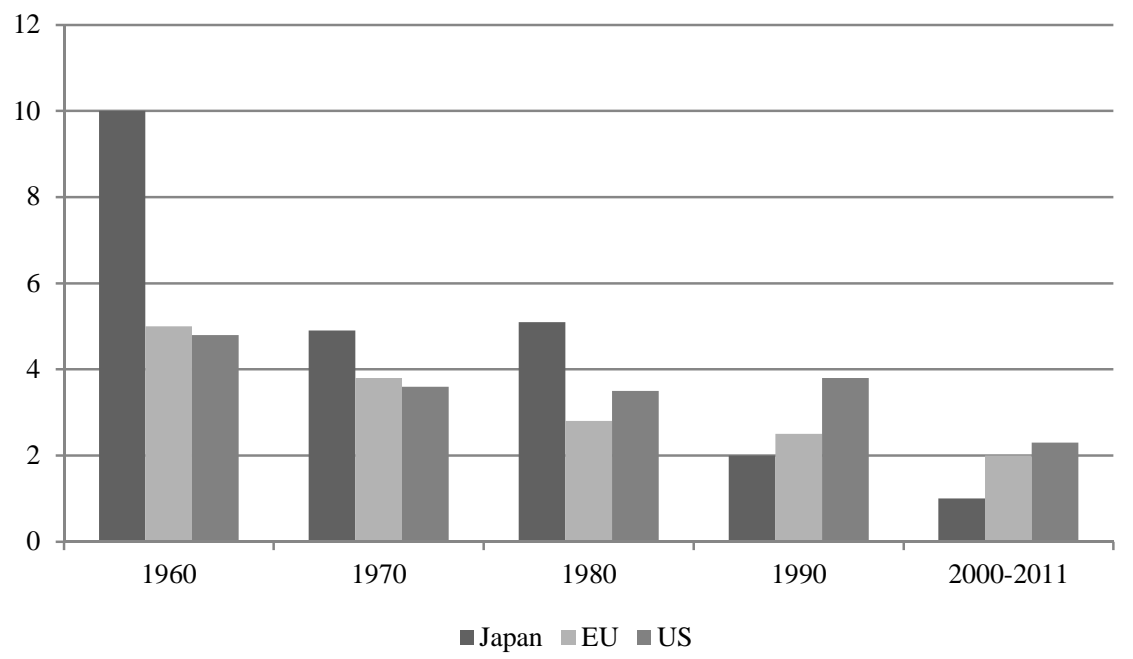

Sources: US Bureau of Economic Analysis, National Income accounts. Retrieved from http://bea.gov/national/nipaweb/SelectTable.asp; World Bank, WDI, Retrieved from http://databank.worldbank.org.

Furthermore, during 1997-98, like all East Asian economies, Japan was hit by crisis. East Asian countries accounted for more than a third of the Japanese export market at that time. In addition, these countries were also the destination for about one-quarter of Japanese banks' total lending. The OECD estimated that the East Asian crisis reduced the Japanese GDP growth rates by $1.5 \%$ to $3 \%$ in 1998 (Richardson et al., 2000).

In 2004, Japanese exports reached 59.4 trillion yen or $11.8 \%$ of the GDP, resulting in a 13.4 trillion yen trade surplus. During the short-lived recovery of 2004, a major portion of foreign demand in the recovery came from China and other East Asian countries. Their share in Japan's total exports in 2003 reached 45.5\%, almost doubling from 23.4\% in 1987 (Siddiqui, 2012b). During the same period the US share declined from $37.5 \%$ to $28.1 \%$. It is clear that high economic growth rates in East Asia, including China, has made the largest contribution to Japanese exports (Siddiqui, 2009c).

A fall in the US dollar or appreciation of the yen adversely affects the Japanese export sectors. Since the exchange rates of most East Asian currencies, including the Chinese renminbi is tied to the US dollar. For exam- 
ple, since 2004 Japan has accumulated more than 439 trillion yen of estimated assets invested overseas in various forms, and the devaluation of the US dollar by $20 \%$, for instance, could cause the huge loss of assets. It would be the equivalent of a reduction by $10 \%$ of the GDP (Boltho \& Corbett, 2000).

Japan has traditionally been a high-saving economy. For instance, Japan's gross national savings regularly exceeded 33\% of the GDP over the period 1960-2000 (OECD, 2001). Domestically, the imbalances between savings and investments after 1992 seem to be mainly due to the collapse of stock markets and property bubbles. Japanese banks found themselves with large bad loans. Rather than forcing them towards bankruptcy and mergers, banks in Japan were allowed by the government to write off these bad loans, while at the same time, they were provided with extra profits through a low bank rate and tax avoidance in the name of losses.

Japan's real interest rates in 1991 was $4.9 \%$, while in the same period this was $4.2 \%$ in the US and $4.5 \%$ in Germany. These rates declined to $3 \%$, $4.6 \%$ and $4.3 \%$ respectively in 1995 , dropping further to $1.8 \%, 3.8 \%, 33 \%$ in 1999. Despite the expectations that a fall in real interest rates would have a favourable impact on borrowing and investments, there is little evidence to support such arguments. At present, Japanese business expectations are strongly influenced by massive overcapacity and low demands, from both domestic consumers and foreign markets.

Japanese Prime Minister, Shinzo Abe faces an uphill struggle. The economy has been in a cycle of deflation and deepening crisis ever since the huge property bubble burst in 1992. Over the past five years, the economy has contracted at a rate of $0.2 \%$ a year. Abe's programme consists of three elements, namely, aggressive monetary policy, flexible fiscal policy and a growth strategy. The government has already spent 10 trillion yen in recent years on public spending and plans to spend a further 5 trillion yen by 2015 . On structural reforms, the government intends to liberalise the electricity and pharmaceutical industries, restructure the agriculture sector and reform the social security system. Moreover, Abe's government has initiated a policy to keep the value of the yen down on foreign exchange markets in the hopes of boosting exports. As a result, by February 2014, the yen had fallen to its lowest rate against the US dollar since 2010. However, the US Treasury has called for G20 members to refrain from devaluation, due to fears that this may precipitate another global slump (Giles, 2013). 


\section{What Went Wrong with the Economy?}

So, how are we to account for the poor performance of the Japanese economy over the last two decades? And what measures should the government take to initiate long-term growth?

Stagnation should be viewed as a result of interaction of the effects of financial de-regulation with the macroeconomic impact of rising inequality. This rising inequality means declining aggregate demands since lowincome groups have a high marginal propensity to consume.

Not only in Japan, but in all developed countries, there has been a sharp increase in income inequality for the last two decades. Top incomes have experienced a spectacular growth (Piketty, 2014). In European countries, the income to wage share fell nearly 10 percentage points of the national income. Several researchers have pointed towards links between rising inequality and the current crisis (Stockhammer, 2013; Stiglitz, 2012; Wade, 2009). Stockhammer (2013) identifies four areas in which rising inequality has contributed towards the current crisis. According to him, rising inequality creates a downward pressures on aggregate demand since poor people have higher marginal propensities to consume. Global financial deregulation has permitted countries to run a large current account deficit for long periods. Higher inequality has increased households debts and, finally, the super-rich tend to hold riskier financial assets than other groups. For instance, the rapid rise in hedge funds and subprime lending since the early 1990s can be linked with the availability of more income in the super-rich groups.

Piketty (2014) argues that, on average, inherited wealth dominates wealth amassed from a life time's labour by a wide margin. Low growth, combined with high levels of inequality, means this crisis will continue. Income distribution in the developed countries has witnessed a sharp shift in favour of higher income groups for the last two decades although there are differences across the countries. Since 1980, wage share has fallen some 10 percentage points in Western Europe and more in Japan. In the US, the top 1\% increased its share of national income from $8 \%$ in 1980 to more than $21 \%$ in 2010. In Japan and Europe, personal income has become more unequal but still to a much more moderate degree than in the US. Based on a sample of developing and developed countries, Jayadev (2007) concludes that the globalisation has had negative effects on the wage share. In a similar study, Stockhammer performed a panel analysis for 71 developing and developed countries and found that financialisation, globalisation and welfare state retrenchment have all contributed to falling wage shares (Stockhammer, 2013, p. 7). 
Falling wage share has had a negative effect on consumer demand, because wage earners and poorer sections will have higher marginal propensity to consume than the recipient of the profits. The overall effect depends on their relative size and a Kaleckian model allows for aggregate demand to be either wage-led or profit-led. A wage-led demand is where a rise in wage share leads to higher aggregate demands, whilst a profit-led demand would have negative effects on aggregate demand. The Kaleckian model predicts that poor groups will have a higher marginal consumption than the rich (Bhaduri \& Marglin, 1990).

A further decline in the fortunes of the Japanese economy can be expected due to its rapid aging population, and the rise in the proportion of older people needing to be cared for. As a result, it has been estimated that the potential growth rate over the next decade cannot rise above $2 \%$. With the stagnation in domestic demands, companies had been reducing their investments, while households have stepped up provisions for old-age care expenses. The labour force has been shrinking for the last two decades as Japan's post-war baby boomers retire and their replacement age cohorts are smaller. Moreover, retirees switch from being savers to dissevers. retirees stop being savers. For instance, in the early 1980 s, only $10 \%$ of its population were in the $65+$ age group and the household savings rate was $17 \%$. By 2012, due to the population bulge caused by the post-war baby boomers, the $65+$ age now makes up $25 \%$ of the total population and saving rates have declined to just $4 \%$ (Berry, 2012). Japan has the fastest aging population in the world and its members have been saving hard and long for their retirement. Despite being a developed economy, the country is not able to create enough investment to absorb those savings.

Table 1 shows the age structure of the Japanese population. The population peaked in 2004 and then fell by some $7 \%$ over the next 25 years. More interesting is the proportion of the total population made up by the $65+$ age group which is expected to rise to one-third, a figure which is double the current level. The labour force, on the other hand, is expected to decrease by $0.6 \%$ annually during the period of $2000-2025$. This reduction in the labour force will also affect economic growth. 
Table 1. Ageing Population in Japan

\begin{tabular}{|c|c|c|c|c|}
\hline \multirow{2}{*}{ Population (Thousands) } & \multicolumn{3}{|c|}{ Share of Age Group (\%) } \\
\cline { 3 - 5 } & & $\begin{array}{c}\text { Age group } \\
\mathbf{0 - 1 4}\end{array}$ & $\begin{array}{c}\text { Age group } \\
\mathbf{1 5 - 6 4}\end{array}$ & $\begin{array}{c}\text { Age group } \\
\mathbf{6 5} \text { and over }\end{array}$ \\
\hline 2000 & 126,892 & 14.7 & 68.1 & 17.2 \\
\hline 2010 & 127,623 & 14.3 & 63.6 & 22.0 \\
\hline 2020 & 124,133 & 13.7 & 59.5 & 26.9 \\
\hline 2030 & 117,149 & 12.7 & 59.3 & 28.0 \\
\hline 2040 & 108,964 & 12.9 & 56.1 & 31.0 \\
\hline 2050 & 100,496 & 13.1 & 54.6 & 32.3 \\
\hline
\end{tabular}

Source: National Institute of Population and Social Security Research (1997), Yoshikawa (2000).

It seems that, despite a brief recovery, the 2008 financial crisis has turned into a deeper crisis in the developed countries. World trade contracted by some $20 \%$ and GDP in most developed economies fell sharply, by $5 \%$ or more (Siddiqui, 2015). This crisis did not only hit those which had earlier experienced property bubbles, but also countries such as Japan and Germany, where property prices were relatively low over the past few years. Since 2009, several countries in the Eurozone have been hit by a sovereign debt crisis and have had to follow austerity policies to build confidence among the global capital. Stockhammer (2013) argues that: "deregulation allowed for a bubble in financial and property markets, which in turn allowed for massive increase in household debts. Rising household debt levels fuelled consumption expenditure [which] led to economic growth that also resulted in the current account deficits" (Stockhammer, 2013, p. 6).

The Japanese banking sector is under government control, which gives it enormous leverages to manipulate investments. Companies face restrictions on raising capital by stock floatation or from foreign creditors. In Japan, competition has been effectively regulated through government guidance, which has encouraged the cross-ownership of shares between the banks and the keiretsu. International financial deregulation has allowed countries to run large current account deficits for long periods. The way out was seen to be either through a debt-led model or an export-led growth model (Stockhammer, 2013). Boltho and Corbett (2000, p. 4) argue that: 
"Past and present deregulatory efforts, aimed at making financial markets more competitive, could, if anything, have the opposite impact at least in the short run. Thus, interest-rate deregulation, for instance, almost certainly worsened the already poor returns of the banking sector in the late 1980s."

Despite its relatively resilient financial system, Japan was severely affected by the global financial crisis (Hoshi \& Kashyap, 2004). Its industrial production declined and became more responsive to external crisis. Over 90\% of Japan's exports consisted of highly income-elastic industrial supplies, capital goods and consumer durables. Although the East Asian economies are growing relatively faster than other regions, and the region has become Japan's largest export destination, East Asia imports from Japan largely consist of intermediate goods used in the production of final goods destined for the US and EU markets.

Japanese corporations have moved much of their manufacturing to countries where both skilled and semi-skilled workers are paid much less, and those new workers cannot possibly consume what they produce. By the same token, consumers in the US and the EU cannot buy much more because their economies are in crisis and their real incomes are stagnant.

Japan used its trade surplus and through external surpluses, the country has financed US current account deficits, either directly by purchasing US bonds and securities, or by taking overseas claims in US dollars rather than yen. There was a tacit understanding between the US Treasury and the Japanese government that Japan will continue to recycle its trade surpluses by purchasing US bonds and securities.

The pegging of the East Asian currencies to the US dollar stimulates the pattern of expectations concerning export prospects and, as a result, outflow of Japanese capital to the region. In reality, future economic prospects between Japan and the East Asian economies depend upon factors such as US strategic interests and policies and stability within the region, over which Japan has no control. The Japanese economy could not become the hub of East Asian production, though it utilizes regional economic dominance in order to expand exports, but at the same time it is unable to guarantee the stability of the region.

Japan has been hit hard by the negative terms of trade with a rise in import prices, especially in oil and other commodities. The downward trend in industrial production closely followed exports. The major factor seems to be related to the global reduction in demand whilst the sharp appreciation of the yen added the adverse impact of the financial crisis on its exports. For instance, the nominal value of yen appreciated by $17 \%$ against the US 
dollar and by $27 \%$ against the euro in the period from September 2008 to January 2009 (Harding, 2013; Kawai \& Takagi, 2009).

Every time the recovery of the Japanese economy looks as though it is picking up it relapses shortly afterwards.

The government had a small surplus in 1991, which soon disappeared. Japan has had a deficit since 1993, which has risen sharply, exceeding 7\% of the GDP from 1999 to 2003. The deepening crisis resulted in the gross public debt rising from nearly $70 \%$ to over $180 \%$ in 2005 . The Bank of Japan initiated monetary policies to lower the discount rate from $4.5 \%$ in January 1992 to $0.5 \%$ in 1995 . In 1999, the interest rates were reduced to virtually zero.

Some economists argue that Japan's fiscal situation is not sustainable due to rising government debt and suggest that only a tax increase of $13 \%$ or drastic budget cuts would ensure economic stability and growth. Japan is the world's third largest economy, and yet it is estimated that the government debt there will exceed the private sector financial assets available for government debt purchase in the next 10 years. Unlike European countries, Japan has not followed fiscal austerity programmers and the country has increased spending, but has had little success in increasing the growth rates (Siddiqui, 2009a).

In April 2014, the Japanese government raised consumption tax (value added tax) from $5 \%$ to $8 \%$ which is likely to slow down consumer spending and ultimately to slow down the economy.

Social and health spending has also risen, for instance, social security spending has increased from $19.7 \%$ of the government budget to more than $31 \%$ between 2000 and 2012. If the government cuts back that would lead to household dissaving. Nevertheless, the domestic pressures caused by rising social costs and mounting debts and debt servicing? call for drastic changes.

Japan has large foreign currency deposits from its earlier boom period. Due to many years of trade surpluses, its big corporations have accumulated vast sums of corporate savings denominated in foreign currencies, mainly in US dollars, but they are controlled by very small number of corporations. If all this capital were to be repatriated, foreign currency would be sold to buy yen, which would drive up the value of yen and ultimately worsen the competitiveness of Japanese exports (Siddiqui, 2009b).

Statistics for 2012 shows that Japan's net debt-to-GDP ratio stands at about $134 \%$, whilst in comparison the US is at $87 \%$ and the UK at $82 \%$ (see Figure 3 and 4). Japan's debt ratio is higher than that of Greece, Italy or Spain. Its debt servicing has also increased, currently standing at $23 \%$ of the GDP, with interest rates at $1 \%$. 
Figure 3. Japanese GDP and gross government debt, \% change

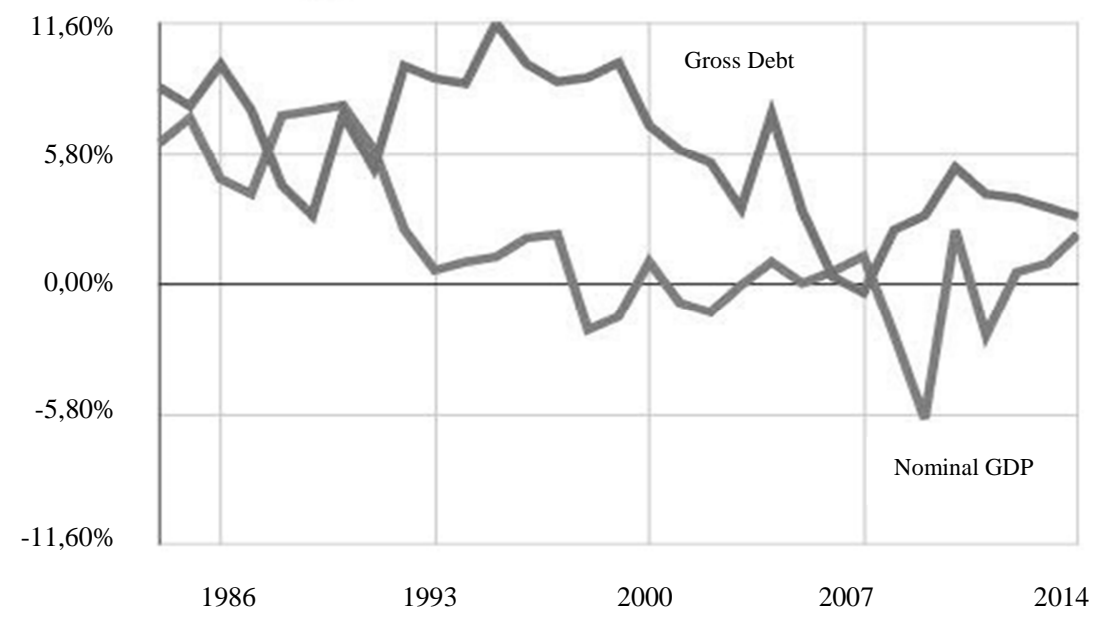

Source: The Economist (2014).

Figure 4. Japanese Debt Servicing and Rates: What Happens Next?

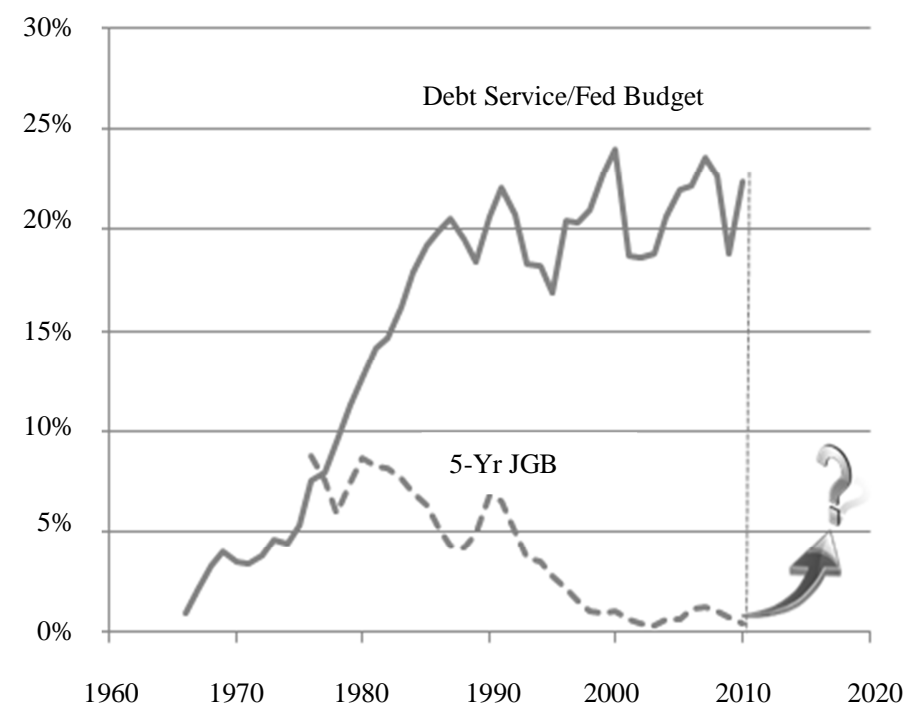

Sources: Ministry of Finance, Bank of Japan, and CFA Institute. 
The reason for Japan being so deeply in debt is due to that fact that the 1992 falling real estate property prices triggered banking crisis and stagnation. The government took control of seven banks whilst various other financial institutions were either closed down or forced to accept merger.

"Loss estimates ranged up to $18 \%$ of GDP and a massive program of public works spending was begun to stimulate the economy. All that spending caused the gross/GDP ratio to soar from about 65\% in 1991 to around $190 \%$ in 2005. Today, with that ratio about percentage point is higher the government may no longer have the wherewithal to mount such a bailout of the banking system." (Berry, 2012, p. 45).

In Japan, it seems that the economy increasingly became dependent on earlier speculative financial bubbles. Later this interdependence increased and there seems to be a clear link between stagnation and financialisation of the economy (Wade, 2009).

About the mounting of government debts in Japan, The Economist (2014) has summarized in the following words:

"the Bank of Japan dramatically scaled up its quantitative easing programme in response to weak growth and inflation figures. Then new data revealed that Japanese economy shrank at a $1.6 \%$ annual pace in the third quarter, when growth had been expected. The consumption tax rise is part of a strategy designed to get Japan's government debt under control: Japanese government debt is now above $240 \%$ of the GDP and the government continues to run deficits of around $8 \%$ of the GDP per year."

Similarly, Ongoing concerns regarding Greece's sovereign debts and its default could deepen the euro crisis. The yields on ten years' worth of Japanese government bonds is about $1 \%$, among the lowest in the world. Nevertheless, the IMF predicted that in 2014, Japan's fiscal deficit would be more than $10 \%$ of its GNP and its debts would have reached $250 \%$ of the GDP. That is more than double the gross debt level of Italy, the most highly indebted country in EU (See Figure, 5). Despite rock-bottom interest rates, Japan is spending nearly half of its tax revenue on debt services. Its deficit is expected to be so huge in the fiscal year 2014 that it will have to borrow more than it collects in taxes. So, why is there still no panic in the bond markets? That is because due to its high domestic savings in the past, the 


\section{Kalim Siddiqui}

Figure 5. Debt as per cent of GDP of developed economies

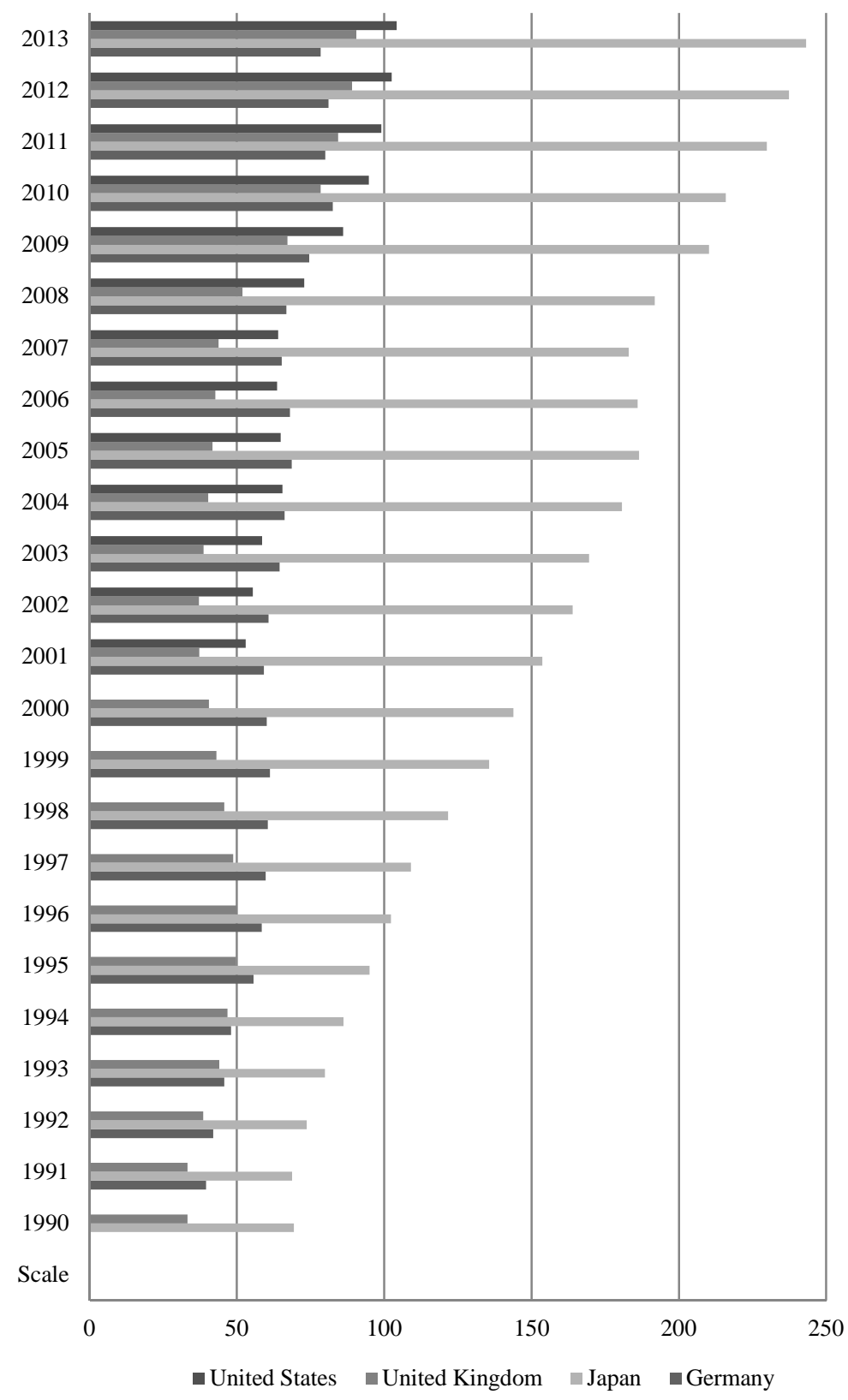

Source: IMF, World Economic Outlook database. Retrieved from http://www.imf.org/exte $\mathrm{rnal} / \mathrm{pubs} / \mathrm{ft} /$ weo/2014/02/weodata/index.aspx. 
government was able to raise money internally and also because money saved from the past decades of trade surpluses enabled it to accumulate trillions of dollars' worth of assets overseas (Wade, 2009).

Such an enormous increase in government debts is the result of a number of specific government policies. Despite the increase in corporate and consumption (sales) taxes, by early 2006, the amount of total public debts had reached 774 trillion yen, nearly double that of the 1995 levels.

It is ironic that by adopting neoliberal policies, the government supposed to targeting state fiscal deficit, has continuously increased the public debt and thus deepened the fiscal crisis of the state. Due to stagnation and declining growth rates government revenue has declined while fiscal deficit has increased steadily since 1990s, as shown in Figure 6.

Figure 6. Japanese Government Revenues vs. Expenditures

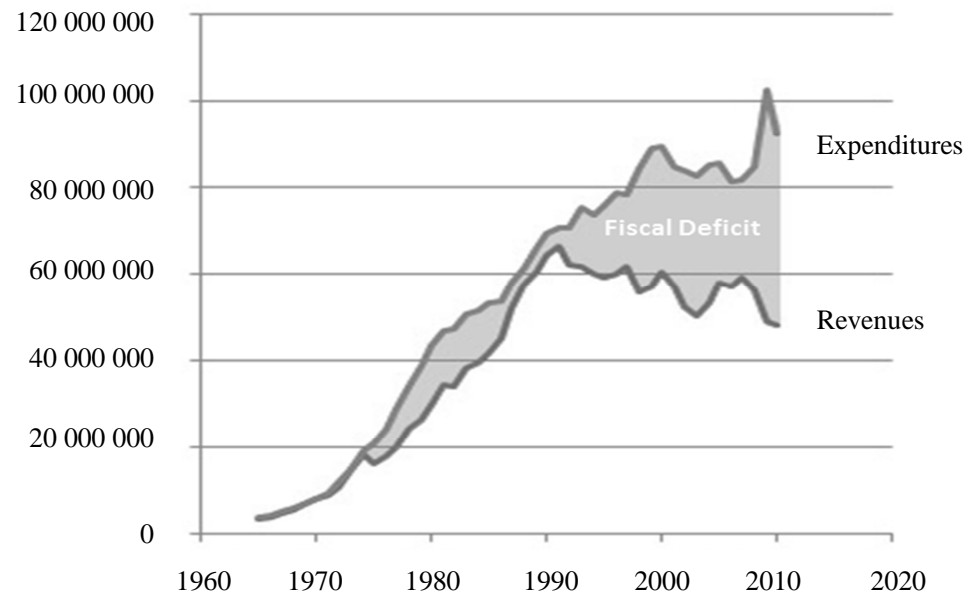

Sources: Ministry of Finance, CFA Institute.

More than half of the country's export market is now in the developing countries including China (Siddiqui, 2009c). However, the global financial crisis of 2008 adversely affected Japan's export, especially in East Asia. Some $86 \%$ of the decline was in industrial supplies and capital goods, whereas the share in US and EU was less i.e. 60\%. As Kawai and Takagi, (2009) note: "Japan was affected by the shrinkage of "triangular trade" where Japan and the Asian newly industrialized economies (Korea), Singapore and Taipei, China) export parts to the China and other emerging Asian 
economies, which in turn assemble then to produce final products for the US and European markets" (Kawai \& Takagi, 2009).Therefore, Japanese exports collapsed because both the export of consumer durables to developed countries and the export of industrial supplies and capital goods to emerging Asian countries fell sharply. This was in addition to the contraction of the markets in North America and the EU due to the global crisis of 2008 , and the austerity programme followed by these governments which further depressed consumer demands and affected Japanese companies' exports to these markets (Kawai \& Takagi, 2009). Over 90\% of Japan's exports consist of highly income-elastic industrial supplies, capital goods and consumer durables. The crisis in the US and the EU markets had a severe impact on the country's exports. In Japan both the export of consumer durables to US and EU, which accounted for nearly $15 \%$ of total exports, and the export of industrial supplies and capital goods to East Asian economies (some $40 \%$ of total exports), were adversely affected by the financial crisis (Siddiqui, 2010). Moreover, intra-regional trade and direct foreign investment have both been affected. Japan's exports to East Asian countries have sharply increased over the last 25 years, with its share of exports to East Asia as a percentage of the total exports rising from 34\% in 1990 to nearly $56 \%$ in 2010.

The international financial crisis in 2008 hit Japan hard. As a highly export-oriented economy, the country witnessed a double impact from the crisis. Its foreign markets in the US and EU receded, due to falling demand in those countries. In addition, yen's status as a "safe haven" currency, led to its appreciation due to economic downturn. The cumulative affect resulted in undermining growth rates and exacer-bated the crisis (Wade, 2009).

In 2012, the Bank of Japan announced plans to expand quantitative easing i.e. buying 10 trillion yen worth of JGBs to spur economic growth and end deflation. The government has proposed to raise consumption tax from 5\% to $10 \%$ by the end of 2015 . Many fear that this would increase household expenditure and contract domestic demands.

\section{Conclusions}

From being the fastest growing economy in the developed world during the period from 1950 to 1989, Japan's economy has now become the slowest. Its economic difficulties could become worse, which would impact the global economy simply due to the fact that this country is currently the third largest importer of primary products and also possesses the largest stock of foreign assets. Moreover, its business and labour practices and 
technological development has been a major contributor not only to its own economy but have also impacted globally in the recent past. The country's future development or lack of it would have much wider consequences beyond the East Asian region.

The neoclassical economists ignore meaningful historical analysis, and their abstract models are constructed around unreal assumptions of perfect competition and market efficiency. These models are geared to legitimise the current system rather than explain it on the basis of laws of motions. Therefore, this study has attempted to examine the case of Japan in relation to its domestic and international situation, considering the interrelation between political and economic aspects, and exploring how these changes have had implications for the economy, both in terms of the post-war boom and the current stagnation.

The economic miracle of post war-decades, the debacle of the economic policies of the 1990s, and the bubble that followed the US treasury's currency intervention of 1985, the Plaza Accord, have all impacted Japan's wider economy, especially its export sector. The economic crisis which began in 1991 was severe and developed into deflation with the economy lying in a 'cryonic state' in which property prices, stock market prices, cost of living and the GDP have all remained stagnant for over two decades. For instance, a litre of juice. Which cost 1 yen in 1991 is still the same price today (Pilling, 2014).

Japan launched a policy which has also been followed recently in the EU and the US i.e. quantitative easing and almost zero interest rates. Government stimulus packages and tax cuts are among the key ingredients of such policies. There are limits to the pursuit of such expansionary policies, which have so far met with little success. The earlier arguments about 'crowding out' seem to have been forgotten by mainstream economists, given the abundance of domestic savings, but the multiplier effects associated with fiscal expansion policies have produced little results so far in Japan. It seems that public spending increases have been concentrated on largely expensive wasteful infrastructures with little consideration of their economic benefits.

Japan's astronomical government debt to GDP ratio of $200 \%$ is the highest in the developed world, but it does not mean that the country will have a debt crisis. As the world's third largest economy, it had the resources to finance the costs of recovery after the Kobe earthquake on its own. It finances its debt almost entirely within Japan. Some 95\% of Japan's government bonds are held domestically. If Japan has to borrow from the rest of the world, then it will become problematic. If the current situation is 
left unresolved, then it will most likely have negative effects on investor confidence.

This study indicates that a more equitable distribution of income and wealth will require a change in tax and wage policy. Wage growth appears to be a precondition for increase in aggregate consumption that does not depend on growth in debt. Taxing the rich more will dampen speculationrelated investment whilst increased investment in welfare measure will distribute wealth more equitably. The present prescription of cutting wages in recession does not help long-term recovery. As Stockhammer (2013, p. 20) suggests,

"more equitable distribution of income and wealth than presently exists would be an essential aspect of a stable growth regime: wage growth is a precondition of an increase in consumption that does not rely on the growth of debt. And financial assets are less likely to be used for speculation if wealth is more broadly distributed."

Reduction in the incomes of the poorest groups leads to increased adverse on the demands. Also growing inequalities and stagnant or falling wages mean that their efforts to try to keep up with consumption norms lead household into increased debts. At the same time, the rising incomes of the tiny minority of super-rich means more money available for speculative investment.

The study concludes that neoliberal 'market-centred' policies have brought inequality, stagnation, and the fiscal crisis of the state in Japan. Therefore, a radical critical political economy is required for more objectively, one involving increased levels of welfare and people-led measures. Japan needs to develop an economy that relies more on domestic demand than on exports. Adopting a more liberal policy on migrant workers would also help to increase private investment in a rapidly aging society.

\section{References}

Aoki, M. (1990). Towards an Economic Model of the Japanese Firm. Journal of Economic Literature, 28(1).

Argitis, G. \& Pitelis, C. N. (2008). Global Financial and Systematic Instability. Contribution to Political Economy, 27(1). DOI: 10.1093/cpe/bzn008.

Berry, J. M. (2012). A Japanese Debt Crisis?. The International Economy, Spring.

Bhaduri, A. \& Marglin, S. (1990). Unemployment and the Real Wages: the economic basis for contesting political ideologies. Cambridge Journal of Economics, 14(4). 
Boltho, A. \& Corbett, J. (2000). The Assessment: Japan's Stagnation - can policy revive the economy. Oxford Review of Economic Policy, 16(2). DOI: 10.1093/oxrep/16.2.1.

Burkett, P. \& Hart-Landsberg, M. (2000). Development, Crisis and Class Struggle: Learning from Japan and East Asia, Basingstoke: Macmillan.

Caballero, R. J, Takeo, H. \& Kashyap, A. K. (2003). Zombie Lending and Depressed Restructuring in Japan. Working Paper, University of Chicago, USA.

Clarke, T. (2010). Recurring Crisis in Anglo-American Corporate Governance. Contribution to Political Economy. 29(1). DOI: 10.1093/cpe/bzq002.

Cowling, K. \& Tomlinson, P. R. (2011). Post the 'Washington Consensus: economic governance and industrial strategies for $21^{\text {st }}$ century. Cambridge Journal of Economics. 35(5). DOI: 10.1093/cje/ber003.

Dore, R.P. (1971). Land Reform and Japan's Economic Development. in T. Shanin (ed.) Peasants and Peasant Societies. Harmondsworth: Penguin Press.

Forsberg, A. (2000). America and the Japanese Miracle: the Cold War Context of the Japan's Post-War Economic Revival. London: Chapel Hill.

Giles, C. (2013). Little Recovery in Advanced Economies. Financial Times, $5^{\text {th }}$ March, London.

Gilpin, R. (2000). The Challenges to Global Capitalism, New Jersey: Princeton University Press.

Harding, R. (2013). Currency Farce Reveals US-Japan Dispute. Financial Times, $13^{\text {th }}$ February, London.

Harrison, F. (1983). The Power in the Land. London: Shepheard-Walwyn.

Hoshi, T. \& Kashyap, A. K. (2004). Japan's Financial Crisis and Economic Stagnation. Journal of Economic Perspective. 18(1). DOI: $10.1257 / 08953300$ 4773563412 .

Itoh, M. (2000). The Japanese Economy Reconsidered. London: Palgrave.

Jayadev, A. (2007). Capital Account Openness and the Labour Share of Income. Cambridge Journal of Economics. 31(3). DOI: 10.1093/cje/bel037.

Johnson, C. (1998). Economic Crisis in East Asia: the clash of capitalisms. Cambridge Journal of Economics. 22(6). DOI: 10.1093/cje/22.6.653.

Johnson, C. (1982) MITI and the Japanese Miracle; The Growth of the Industrial Policy 1925-1975. Stanford CA: Stanford University Press.

Kawai, M. \& Takagi, S. (2009), Why was Japan hit hard by the Global Financial Crisis? Tokyo: Asian Development Bank Institute. Retrieved form http://www.adbi.org/working-paper/2009/10/05/3343.japan.gfc/.

Krugman, P. (1999). Japan Heads for Edge. Financial Times. $20^{\text {th }}$ January, London.

Krugman, P. (1994). The Myth of Asia's Miracle. Foreign Affairs. 73.

Little, I. (1982). Economic Development: Theory Policy and International Relations. New York: Basic Books.

Maddison, A. (1995). Monitoring the World Economy, 1820-1992. Paris: OECD.

Mayer, C. (1999). Financial Instability. Oxford Review of Economic Policy. 15(3). DOI: $10.1093 /$ oxrep/15.3.1. 
METI (2012). Vision of Economic Society - Maturity and Diversity, New Industrial Structure Committee of the Industrial Structure Council, Ministry of Economy. Trade and Industry: Tokyo.

METI (2010). Japan's Manufacturing Industry. Ministry of Economy. Trade and Industry: Tokyo.

OECD (2013). Economic Survey - Japan. Paris: OECD

Ogura, T. (1967). Agrarian Problems and Agricultural Policy in Japan: A Historical Sketch. Tokyo: Institute of Asian Economic Affairs.

Piketty, T. (2014). Capital in the Twenty-first Century. Cambridge Mass.

Pilling, D. (2014). Bending Adversity: JAPAN and the Arts of Survival. London: Allen Lane.

Richardson, P., Visco, I., \& Giorno, C. (2000). Predicting the Evolution and Effects of the East Asian Crisis from the OECD Perspective. Economic Department Working Paper. 236, Paris: OECD

Sachs, J. (2001). The Benefits of a Weaker Yen. Financial Times. $18^{\text {th }}$ April, London.

Sako, M. (1996). Suppliers Associations in the Japanese Auto industry; Collective Action for Technology Diffusion. Cambridge Journal of Economics, 20(6).

Siddiqui, K. (2015). Trade Liberalisation and Economic Development: A Critical Review. International Journal of Political Economy. 44 (3). DOI: 10.1080/08911916.2015.1095050.

Siddiqui, K. (2014a). Flows of Foreign Capital into Developing Countries: A Critical Review. Journal of International Business and Economics, 2(1).

Siddiqui, K. (2014b). Higher Education in the Era of Globalisation. International Journal of Humanities and Social Science, 3(2).

Siddiqui, K. (2013). Experiences of Developmental State in India and Taiwan. Think India Quarterly, 16(4).

Siddiqui, K. (2012a). Malaysia's Socio-Economic Transformation in Historical Perspective. International Journal of Business and General Management. 1(2).

Siddiqui, K. (2012b). Developing Countries Experience with Neoliberalism and Globalisation. Research in Applied Economics, 4(4). DOI: http://dx.doi.org/ 10.5296/rae.v4i4.2878.

Siddiqui, K. (2010). The Political Economy of Development in Singapore. Research in Applied Economics, 2(2). DOI: http://dx.doi.org/10.5296/rae.v2i2. 524.

Siddiqui, K. (2009a). Japan's Economic Crisis. Research in Applied Economics, $1(1)$.

Siddiqui, K. (2009b). The Current Financial Crisis and its Impact on the Emerging Economies - China and India. Research in Applied Economics, 1(2).

Siddiqui, K. (2009c). The Political Economy of Growth in China and India. Journal of Asian Public Policy, 1(2). DOI: 10.1080/17516230902734528.

Siddiqui, K. (1995). Role of the State in South-East Asia. The Nation. $27^{\text {th }}$ May.

Stiglitz, J. (2012). The Price of Inequality: The Avoidable Causes of Invisible Costs of Inequality. New York: Norton 
Stockhammer, E. (2013). Rising Inequality as a Cause of the Present Crisis. Cambridge Journal of Economics, 26. DOI: $10.1093 /$ cje/bet052.

The Economist (2014). Japan's Economy - About that Debt. $18^{\text {th }}$ November, London.

The Economist (2009). Japan - The Incredible Shrinking Economy. $4^{\text {th }}$ April, 7374 , London.

Tsuru, S. (1993). Japan's Capitalism: creative defeat and beyond. London: Cambridge University Press.

Wade, R. (2009). The Global Slump, Deeper Causes and Harder Lessons. Challenge, 52(5). DOI: 10.2753/0577-5132520501.

World Bank (1993). The East Asian Miracle: Economic Growth and Public Policy. New York: Oxford University Press.

Yoshikawa, H. (2000). Technical Progress and the Growth of the Japanese Economy - past and future. Oxford Review of Economic Policy, 16(2). DOI: $\underline{10.1093 / o x r e p / 16.2 .34}$. 

